PDFlib PLOP: PDF Linearization, Optimization, Protection

Page inserted by evaluation version www.pdflib.com - sales@pdflib.com 


\title{
Political Context, Issue Salience, and Selective Attentiveness: Constituent Knowledge of the Clarence Thomas Confirmation Vote
}

\author{
Vincent L. Hutchings \\ University of Michigan
}

\begin{abstract}
According to the issue salience hypothesis, citizens tend to acquire information on subjects they perceive as important. However, past efforts to demonstrate this have been mixed. I argue that this is because scholars often fail to recognize the importance of overlapping group memberships. I maintain that different group memberships - a traditional proxy for issue salience - can cancel out effects if they are in conflict. Some research has also shown that cues in the political environment increase levels of political information. Extending this line of research, I hypothesize that the interaction of salience with environmental cues influences both information and participation levels. I find that an examination of the confirmation vote for Supreme Court Justice Clarence Thomas largely confirms these hypotheses.
\end{abstract}

$\mathbf{P}_{\mathrm{u}}$ ublic opinion research has consistently shown that citizens are not routinely attentive to matters of public policy (Bennett 1995; Converse 1964; Smith 1989). This uncomfortable reality presents some obvious difficulties for the normative ideal of responsive government inherent in democratic theory. Political scientists have developed a number of ways to reconcile the "shortcomings" of the electorate with the responsibilities required of them in a representative democracy. One of the more popular explanations is issue salience. This theory holds that while citizens may be generally uninformed, they are often knowledgeable on issues that they consider important. A common way of testing this theory is to examine whether members of particular social groups are more informed about policies directly relevant to their group.

Other explanations for variation in information levels focus on factors external to the individual. For example, one argument maintains that citizens are ill informed about politics because the news media do not provide sufficient coverage of policy matters (Patterson 1994). When the media do focus on these

I thank Chris Achen, Nancy Burns, Frank Gilliam, Don Kinder, Kathleen Knight, Brian McKenzie, Harwood McClerking, Hanes Walton, and John Zaller for helpful comments on various drafts of this paper.

THE JOURNAL OF POLITICS, Vol. 63, No. 3, August 2001, Pp. 846-868

(C) 2001 Blackwell Publishers, 350 Main St., Malden, MA 02148, USA, and 108 Cowley Road, Oxford OX4 1JF, UK. 
issues, citizens show a sizable increase in information levels (Delli Carpini and Keeter 1996). According to another argument, citizens are more likely to be attentive to politics when cues in their environment suggest that their attentiveness is warranted (Bobo and Gilliam 1990; Delli Carpini and Keeter 1996).

Whereas each of these factors likely affects levels of political information, previous research has not always supported these theories. In the case of the issue salience hypothesis, results have largely been mixed (Delli Carpini and Keeter 1996; Iyengar 1990; Price and Zaller 1993). I argue that part of the reason for this is that previous research has neglected the importance of overlapping group identities. That is, compatible group identities can combine to facilitate selective attentiveness just as conflicting identities can work to suppress it. When the interaction of different group identities is considered, evidence for the issue salience hypothesis should become stronger.

This article examines the issue salience hypothesis by focusing on a recent high-profile vote in the U.S. Senate: the vote to confirm Clarence Thomas to the Supreme Court. The Thomas vote provides an excellent opportunity to test this hypothesis because the controversy surrounding it raised prominently the issues of race, gender, and ideology. A naive test of this hypothesis would merely examine whether blacks, women, and ideologues were more attentive than other citizens to this vote. I argue that a more nuanced approach is required. For example, the issues raised during the Hill-Thomas hearings were just as likely to be salient to some men as they were to some women. As argued more fully below, liberal women and conservative men should have been particularly interested in the outcome of the vote.

In addition to individual level differences, citizens also encountered important differences in their informational and political environments that should have affected knowledge of this vote. For example, some senators faced reelection not long after the Thomas vote and encountered challengers who were likely to campaign on the issue. Additionally, some voters also resided in states where the local political circumstances encouraged more attentiveness to this roll call. That is, for some senators the political implications of the vote were particularly conspicuous.

The link between the informational environment and levels of political knowledge seems plausible, and some previous work has already established a connection. Research on the effects of the political environment, however, has been rare. Most work on the effects of the political environment focuses on participation rates or public opinion. Little work has been done showing that cues in the political environment can also motivate greater levels of attentiveness. I argue that context effects of this kind, even subtle ones, can affect levels of attentiveness to political information. Moreover, individual perceptions of issue salience should interact with cues in the political environment to bolster citizen information levels. I argue that not only do issue salience and the political (and informational) context contribute separately to political information levels, but that their effects can also manifest themselves jointly. 
This perspective on the importance of context and salience may also help to determine if the Thomas vote had any impact on the 1992 Senate elections. In other words, a consideration of individual and environmental factors might indicate whether this issue had any influence on the voter's candidate choice. In order to answer this question, I argue that we need to know which voters were most interested in this issue and whether the political context provided an opportunity to reward or punish the incumbent.

Finally, this examination of the Thomas vote contributes to the debate on the acquisition of political information. One set of scholars argues that citizens are "information specialists" or tend to absorb information primarily on topics that interest them (see especially Iyengar 1990). Others argue that citizens are instead more likely to be "generalists" (Delli Carpini and Keeter 1996; Price and Zaller 1993). According to this perspective individuals who are generally well informed about politics also tend to learn about specific political stories regardless of their interest in the story. Since the survey data used for this paper carry adequate measures of both concepts, we can learn which perspective generates the best explanation on a key Senate roll call vote.

\section{Literature Review and Theoretical Expectations}

While much of the public opinion literature finds low levels of voter knowledge, research on domain-specific attentiveness indicates that this may be overstated (Iyengar 1990; Krosnick 1990; McGraw and Pinney 1990). Scholars in this literature find that the "costs" of becoming well-informed on more than a few issues are too great for most people. Instead, individuals focus on issues that are personally relevant to them or salient reference groups (Berelson, Lazarsfeld, and McPhee 1954; Conover 1984; Converse 1964; McGraw and Pinney 1990; Turner et al. 1987). For example, Iyengar shows that blacks, Jews, and blue-collar workers are more informed than other citizens about issues affecting their groups (Iyengar 1990; Price and Zaller 1993).

While some research has found evidence of domain specific attentiveness, other studies have found more limited support for this theory (Delli Carpini and Keeter 1996; Nueman 1986; Price and Zaller 1993). These studies find that even when some citizens care deeply about an issue, they are not always more informed about the issue. Moreover, they do not consistently rely upon the issue when evaluating political candidates (Wolpert and Gimpel 1997).

Research in the field of social psychology may help to explain when domainspecific effects should be present. Self-Categorization Theory explains the circumstances required to elicit group-specific attentiveness (Turner et al. 1987). According to this theory, group membership has the biggest influence on perceptions when the group identification is both readily accessible (i.e., identification is strong) and the social stimuli "fit" with the relevant group identity. In other words, the relationship between issue salience and attentiveness is estab- 
lished when a group identity is "primed" by environmental factors (Iyengar and Kinder 1987; Turner et al. 1987; Verba, Burns, and Scholzman 1997). Thus, the framing of the Thomas vote in explicitly racial, gender, and ideological terms should have prompted selective attentiveness among blacks, women, and ideologues.

Of course, citizens could belong to more than one of these groups. However, multiple memberships would not necessarily enhance salience effects particularly if those memberships were in conflict. As the early Columbia and Michigan models found, conflicting group identities are associated with less accurate political perceptions, lower levels of political participation, and less interest in politics (Berelson, Lazarsfeld, and McPhee 1954; Campbell et al. 1960). I therefore do not expect to find evidence of selective attentiveness among women generally, but rather only among ideologically liberal women. This is because this group's ideological and gender identities were largely consistent on the Thomas vote. Conservative women, on the other hand, were more likely torn between their gender and their ideology. As a result, their divided political sympathies should result in less interest in the outcome of the vote, and hence less attentiveness. The same applies to liberal men who, as men, may have felt some sympathy for Thomas but, as liberals, opposed his stand on the issues. Finally, conservative men should also demonstrate heightened attentiveness on the Thomas vote as they were inclined to feel little conflict on the issue. ${ }^{1}$

Additional contextual variables beyond the content of the vote may have also stimulated attentiveness. As Delli Carpini and Keeter indicate, few examinations of the determinants of political information include context variables (Delli Carpini and Keeter 1996). By context, they mean both the informational context (i.e., greater media coverage in a particular geographic region) and the political context (i.e., local political circumstances that encourage greater interest and knowledge). It is possible that both effects were present for the Thomas confirmation vote.

Previous research has shown that citizens are more informed on political matters in areas with heavier media coverage (Chaffee and Wilson 1977). Thus, citizens should be more informed on the Thomas vote in states that provided greater media attention to the issue. Although the amount of press coverage probably did not vary much across states at the time of the vote, some citizens were more likely to be reminded of their senator's position during the 1992 campaign season. Moreover, some of these senators faced female challengers who were especially outspoken on this vote (Cook, Thomas, and Wilcox 1994; Paolino 1995; Sapiro and Conover 1997).

The different political contexts each senator faced may also have contributed to knowledge of this vote. There is little scholarship on the relationship be-

\footnotetext{
${ }^{1}$ Analysis of Senate Election Study survey data shows that a clear majority of liberal women (59\%) opposed the nomination and a clear majority of conservative men $(60 \%)$ supported it. Less than half of liberal men and conservative women, however, sided with their ideological counterparts.
} 
tween political context and political knowledge. An important exception can be found in the work of Bobo and Gilliam (1990). They find that blacks are more informed about local politics when an African American occupies the mayor's office because this implies greater policy responsiveness to black interests. I agree that forces in the political environment can encourage increased attentiveness to politics. However, the present study focuses upon different elements in the political environment. I argue that citizens can also be motivated by the perception that their political interests are threatened (Marcus and Mackuen 1993). Contextual cues conveying this message need not rely on who occupies a prominent political office. They can instead turn on something as subtle as the political circumstances surrounding an important vote.

To my knowledge, no previous work has addressed whether small differences in the political context can affect knowledge of the issue positions of politicians. Moreover, we do not know if factors in the political environment and intense interest in an issue can work interactively to increase information levels. The Thomas vote provides us with an opportunity to examine these unexplored areas. This is because media coverage of this vote was qualitatively different in states represented by swing Democrats. As described below, the media made it clear that the fate of the nomination rested with these senators. I hypothesize that residents in these states would be especially attentive to their senator's vote because the political stakes surrounding it were higher there. This enhanced attentiveness should be even greater among the issue publics examined in this article. This is especially true of African Americans. Most of the swing Democrats represented southern states with large black constituencies and they could ill-afford to alienate these voters (Overby et al. 1992).

\section{Background}

Although Thomas is a conservative Republican and was opposed by many civil rights organizations, blacks were nevertheless more supportive of his nomination than were whites. This was especially true after Oklahoma law professor Anita Hill raised charges of sexual harassment (Caldeira and Smith 1996). Also, a surprising number of black elites came out in support of the nomination. For example, Virginia Governor Douglas Wilder, Rev. Joseph Lowery of the Southern Christian Leadership Conference, Niara Sudarkasa, president of Lincoln University, columnist William Raspberry, Harvard sociologist Orlando Patterson, and poet Maya Angelou all supported Thomas (Burnham 1992; Marable, 1992; Pinderhughes 1992). Many local leaders supported Thomas as well, even as they rejected his conservative political views (Pinderhughes 1992).

The reaction to the harassment charges was more disjointed among women. Many liberal women, already suspicious of Thomas because of his evasiveness on the abortion question, viewed the charges as an additional reason to oppose the nomination. Moreover, Thomas faced relatively strong opposition from white 
women (Caldeira and Smith 1996; Mansbridge and Tate 1992). Still, overall a majority of women (white and black) supported Thomas.

Responses to the Thomas nomination were largely positive in the Democratically controlled Senate before Anita Hill's allegations were raised. After the first set of hearings, thirteen Democratic senators, more than enough to ensure confirmation, announced their support for Thomas. Most of these senators were from the South. After the charges of sexual harassment were made public, the votes of these thirteen swing Democrats, six of whom were up for reelection in 1992 , were seen as critical to the success or failure of the nomination. ${ }^{2}$

Once the second round of hearings was completed, many of the swing Democrats agonized over their decision and sought advice from family and coworkers. For example, Senator Joseph Lieberman (D-CT) decided to oppose the nomination only after speaking with his 22-year-old daughter. He described the vote as the most difficult he has cast in his three years in the Senate. Senator Richard Bryan (D-NV) said, "In 25 years, this is the toughest vote I've had to cast." ${ }^{3}$ He received more calls from his constituents on this matter than on the Persian Gulf war, with most favoring Judge Thomas.

Although some swing Democrats were concerned about how female staff or family members would react to the vote, many more were concerned with how their black constituents would respond. This was especially true in the South. For example, the Charlotte Observer noted the following:

\begin{abstract}
While some female leaders were expressing disappointment with Hollings (D-SC) for his pro-Thomas stance, he was receiving support from another important political group-the state's elected black officials. Many were warm in their praise of the senator for sticking by the nominee. "It was the right thing to do," said state Sen. Herbert Fielding, D-Charleston, chairman of the Legislative Black Caucus. Feminists who opposed Thomas's nomination said they were not a potent political force in South Carolina to compete with black constituents for Holling's support. ${ }^{4}$
\end{abstract}

Both journalists and political scientists believed that swing Democrats with large African American constituencies provided Thomas with his margin of victory (Overby et al. 1992). In fact, some journalists argued that the Bush administration shrewdly used black support for Thomas to pressure these ambivalent

\footnotetext{
${ }^{2}$ Berke, Richard L. "Senators Who Switched Tell of Political Torment." New York Times, Wednesday, October 16, 1991. The 13 swing Democrats were Senators Boren (OK), Breaux (LA), Bryan (NV), Dixon (IL), Exon (NE), Fowler (GA), Hollings (SC), Johnston (LA), Lieberman (CT), Nunn (GA), Reid (NV), Robb (VA), and Shelby (AL).

${ }^{3}$ Ibid.

${ }^{4}$ Bandy, Lee. "Hollings: 'Bottom Line' Is President's Right To Pick." Charlotte Observer October 16, 1991. The Memphis Commercial Appeal also reported that "A number of Southern Democrats are up for election next year after narrow victories in 1986 and they noted privately that black voters in their states backed Judge Thomas." Rowley, James. "Senate Confirms Thomas, 52-48, To High Court: After Bitter Debate Judge Gets Key Votes of Southern Dems." Memphis Commercial Appeal. Wednesday, October 16, 1991.
} 
Democrats. The New Orleans Times Picayune described the political situation in the South as follows:

In charging racism, Thomas appeared to gain support from black viewers-an important consideration for many of the swing Democratic senators because their states have large black populations. President Bush sought to put further pressure on the wavering Democrats [the day before the vote] by publicly thanking blacks for siding with Thomas. ${ }^{5}$

In the end, only three of the thirteen swing Democrats - Senators Bryan (D-NV), Lieberman (D-CT) and Reid (D-NV) — voted against the nomination. None of the swing Democrats from the South switched his vote. Thomas was confirmed on October 15, 1991, with a 52-48 vote, the lowest margin of victory of any successful nominee in the $20^{\text {th }}$ century.

\section{Data and Measures}

The data for my analyses were drawn from the 1992 portion of the Senate Election Study (SES). This survey is useful for two reasons. First, the SES was designed to draw a random sample of roughly 60 respondents from each of the 50 states. Thus, comparisons can be made across states in a way that has rarely been possible before. Secondly, respondents were asked several questions about the Hill-Thomas hearings including how their senators voted. Those who said they knew and those who were prepared to guess are treated the same in this study.

The main dependent variable in this study is the respondent's ability to recall accurately how their senators voted on the confirmation of Clarence Thomas to the US Supreme Court. When results from the full sample are analyzed, this variable has three possible values: $0,0.5,1.0$. Respondents coded as " 1 " accurately identified each senator's vote, whereas a score of " 0.5 " represents accurate knowledge of only one senator's vote, and " 0 " represents incorrect responses for both senators or an inability to provide an answer. Some additional analysis were also done on the Persian Gulf War vote and the standard political information scale (also coded $0-1) .^{6}$ The point of including these variables was to provide a baseline for comparison with the Thomas model.

As indicated above, expectations of selective attentiveness were located at both the individual level and the environmental or contextual level. The relevant individual level variables are race (black or white respondents only), gender, and ideology. Ideology was measured in two ways. First and most broadly, ideology was measured with the standard 7-point ideological scale. I recoded this scale so that higher values represented a more liberal political orientation.

\footnotetext{
${ }^{5}$ Green, Charles and R. A. Zaldivar. "Public Support May Have Been What Put Thomas Over the Top." New Orleans Time Picayune October 16, 1991.

${ }^{6}$ The SES asked respondents to identify the political office of several individuals as means of gauging political knowledge. These individuals were William Rehnquist, Dan Quayle, Tom Foley, and $\mathrm{Al}$ Gore.
} 
The second measure of ideology was a respondent's position on the abortion question. This variable ranges from 1-3 with higher values indicating more support for abortion rights.

The contextual or environmental measures of selective attentiveness are the presence of a reelection campaign in the state, the relative competitiveness of this campaign, the presence of female candidates in the reelection campaign, ${ }^{7}$ and residence in a state represented by a swing Democrat. Competitiveness was measured with Congressional Quarterly's assessment of the incumbent's electoral prospects and ranges from $0-4$, with higher values indicating greater competitiveness. Open seat contests were not included in any of the contextual variables.

Given my expectation that some group members should be more informed of their senator's vote than others should, I have also included a number of interaction terms. These included interactions for race by residence in a state with a swing Democrat, gender by ideology, and gender by abortion attitude. The following models also included a number of standard control variables. These variables are the respondent's education, age, length of residence in the state, reported media usage, level of interest in campaigns, support or opposition to the Thomas nomination, and partisan and ideological strength. The level of general political information, described above as one of the dependent variables, also doubled as one of the control variables in the Thomas and Gulf War models. Separate analysis by gender showed that the information and ideological strength variables performed differently for men and women. For this reason, these variables were interacted with gender in the analysis presented below.

\section{Results}

Table 1 reports mean levels of knowledge on the confirmation vote by gender, race, and ideology. Results are also presented for overall levels of political information and knowledge of the Gulf War vote, for comparison purposes. Is there evidence of selective attentiveness? Overall, the results in Table 1 are mixed. For example, the data in Table 1 show that no clear pattern emerges for liberal women. They are more knowledgeable than their conservative counterparts across all three measures. Also, as expected, there is no significant difference between liberal men and liberal women on the Thomas vote. However, there are also no significant differences on the other measures of political knowledge.

Results for conservative men are also inconclusive. On the one hand, I found that there were no significant differences between conservative and liberal men

\footnotetext{
${ }^{7}$ The states included in this variable are Arizona, California, Illinois, Iowa, Kansas, Maryland, Missouri, Pennsylvania, and South Dakota. Carol Mosley Braun (D-IL) competed for an open seat in the general election but is also included because she defeated an incumbent in the primary. Barbara Mikulski (D-MD) was the only female incumbent facing reelection.
} 
TABLE 1

Mean Political Information Levels and Knowledge of Senator's Vote on the Confirmation of Clarence Thomas to the US Supreme Court by Race, Gender, and Ideology

\begin{tabular}{|c|c|c|c|}
\hline & $\begin{array}{l}\text { Political } \\
\text { Information }\end{array}$ & $\begin{array}{l}\text { Gulf War } \\
\text { Vote }\end{array}$ & $\begin{array}{c}\text { Thomas } \\
\text { Vote }\end{array}$ \\
\hline Women & $\begin{array}{c}.43 \\
(1374)\end{array}$ & $\begin{array}{c}.51 \\
(1402)\end{array}$ & $\begin{array}{c}.42 \\
(1427)\end{array}$ \\
\hline Men & $\begin{array}{c}.48^{\mathrm{a}} \\
(1149)\end{array}$ & $\begin{array}{c}.65^{\mathrm{a}} \\
(1162)\end{array}$ & $\begin{array}{c}.51^{\mathrm{a}} \\
(1181)\end{array}$ \\
\hline Blacks & $\begin{array}{c}.35 \\
(196)\end{array}$ & $\begin{array}{c}.49 \\
(203)\end{array}$ & $\begin{array}{c}.43 \\
(204)\end{array}$ \\
\hline Women & $\begin{array}{c}.32 \\
(115)\end{array}$ & $\begin{array}{c}.43 \\
(119)\end{array}$ & $\begin{array}{c}.41 \\
(119)\end{array}$ \\
\hline Men & $\begin{array}{l}.39^{\mathrm{b}} \\
(81)\end{array}$ & $\begin{array}{l}.57^{\mathrm{b}} \\
(84)\end{array}$ & $\begin{array}{c}.46 \\
(85)\end{array}$ \\
\hline Whites & $\begin{array}{c}.46^{\mathrm{a}} \\
(2397)\end{array}$ & $\begin{array}{c}.58^{\mathrm{a}} \\
(2361)\end{array}$ & $\begin{array}{c}.46 \\
(2404)\end{array}$ \\
\hline Women & $\begin{array}{c}.44^{\mathrm{c}} \\
(1259)\end{array}$ & $\begin{array}{c}.51^{\mathrm{c}} \\
(1283)\end{array}$ & $\begin{array}{c}.42 \\
(1308)\end{array}$ \\
\hline Men & $\begin{array}{c}.48^{\mathrm{b}, \mathrm{c}} \\
(1068)\end{array}$ & $\begin{array}{c}.66^{\mathrm{b}, \mathrm{c}} \\
(1078)\end{array}$ & $\begin{array}{c}.52^{\mathrm{b}} \\
(1096)\end{array}$ \\
\hline \multicolumn{4}{|l|}{ Ideology } \\
\hline Liberal Women & $\begin{array}{c}.51 \\
(267)\end{array}$ & $\begin{array}{c}.63 \\
(278)\end{array}$ & $\begin{array}{c}.53 \\
(285)\end{array}$ \\
\hline Liberal Men & $\begin{array}{c}.52 \\
(218)\end{array}$ & $\begin{array}{c}.67 \\
(229)\end{array}$ & $\begin{array}{c}.53 \\
(232)\end{array}$ \\
\hline Conservative Women & $\begin{array}{l}.44^{\mathrm{c}} \\
(450)\end{array}$ & $\begin{array}{c}.55^{\mathrm{c}} \\
(458)\end{array}$ & $\begin{array}{l}.44^{\mathrm{c}} \\
(465)\end{array}$ \\
\hline Conservative Men & $\begin{array}{l}.50^{\mathrm{a}} \\
(461)\end{array}$ & $\begin{array}{l}.70^{\mathrm{a}} \\
(460)\end{array}$ & $\begin{array}{c}.58^{\mathrm{a}} \\
(470)\end{array}$ \\
\hline All Cases & .45 & .57 & .46 \\
\hline
\end{tabular}

Note: Number of cases in parentheses. ${ }^{\text {a }}$ Significant difference across gender or race at $p \leq .05 ;{ }^{\mathrm{b}}$ Significant differences across gender within racial groups at $p \leq .05 ;{ }^{\mathrm{c}}$ Significant difference across race or ideology within gender group at $p \leq .05$.

on the Thomas vote. On the other hand, these two groups also did not differ on the Gulf War vote and the political information scale. Also, overall accuracy rates were lower on the Thomas vote than the Gulf War vote, and differences between conservative men and women were somewhat higher for the Gulf War vote. 
The data in Table 1 are less ambiguous with regard to African Americans. Although blacks were significantly less likely than whites to be informed about general political matters and their senator's vote on the Gulf War initiative, the difference on the Thomas vote were mild and statistically insignificant. These results suggest that the racial gap in political knowledge declines significantly on issues salient to blacks.

Uncovering evidence of individual differences in knowledge levels on the Thomas vote is important, but it only represents half of my argument. I also expect differences based on the political and informational environment of the respondent. These results are shown in Table 2. The first two columns report effects for the presence of female Senate candidates. I expect that female candidates were more likely to draw attention to the incumbent's vote on the Thomas nomination and thus respondents should be more informed in these states. However, because there was no theoretical reason why this variable should affect information about the senator whose term was not up,

\section{TABLE 2}

Mean Knowledge of Senator's Vote on Confirmation of Clarence Thomas to the US Supreme Court by Political Context and Race, Gender, and Ideology

\begin{tabular}{|c|c|c|c|c|c|c|}
\hline & $\begin{array}{c}\text { No Female } \\
\text { Cand. in State }\end{array}$ & $\begin{array}{l}\text { Female Cand. } \\
\text { in State }\end{array}$ & F-Stat & $\begin{array}{l}\text { No Swing } \\
\text { Democrats }\end{array}$ & $\begin{array}{c}\text { Swing } \\
\text { Democrats }\end{array}$ & F-Stat \\
\hline $\begin{array}{l}\text { Women } \\
\text { Men }\end{array}$ & $\begin{array}{l}.36 \\
.44^{\mathrm{a}}\end{array}$ & $\begin{array}{l}.51 \\
.61^{\mathrm{a}}\end{array}$ & $\begin{array}{l}19.10^{*} \\
31.55^{*}\end{array}$ & $\begin{array}{l}.42 \\
.51^{\mathrm{a}}\end{array}$ & $\begin{array}{l}.43 \\
.51^{\mathrm{a}}\end{array}$ & $\begin{array}{l}.0648 \\
.0586\end{array}$ \\
\hline $\begin{array}{l}\text { Blacks } \\
\text { Women } \\
\text { Men }\end{array}$ & $\begin{array}{l}.43 \\
.41 \\
.47\end{array}$ & $\begin{array}{l}.56 \\
.59 \\
.53\end{array}$ & $\begin{array}{r}1.71 \\
1.79 \\
.18\end{array}$ & $\begin{array}{l}.37 \\
.36 \\
.39\end{array}$ & $\begin{array}{l}.51 \\
.47 \\
.58\end{array}$ & $\begin{array}{l}5.65^{*} \\
2.23 \\
4.30^{*}\end{array}$ \\
\hline $\begin{array}{l}\text { Whites } \\
\text { Women } \\
\text { Men }\end{array}$ & $\begin{array}{l}.40 \\
.36 \\
.46^{\mathrm{b}}\end{array}$ & $\begin{array}{l}.59 \\
.51 \\
.69^{\mathrm{b}}\end{array}$ & $\begin{array}{l}43.85^{*} \\
17.32^{*} \\
28.40^{*}\end{array}$ & $\begin{array}{l}.47^{\mathrm{a}} \\
.42 \\
.52^{\mathrm{b}, \mathrm{c}}\end{array}$ & $\begin{array}{l}.45 \\
.41 \\
.49^{\mathrm{b}}\end{array}$ & $\begin{array}{l}.6205 \\
.0669 \\
.6653\end{array}$ \\
\hline $\begin{array}{l}\text { Ideology } \\
\text { Liberal Women } \\
\text { Liberal Men }\end{array}$ & $\begin{array}{l}.48 \\
.46\end{array}$ & $\begin{array}{l}.61 \\
.68\end{array}$ & $\begin{array}{l}2.21 \\
5.82 *\end{array}$ & $\begin{array}{l}.52 \\
.54\end{array}$ & $\begin{array}{l}.57 \\
.49\end{array}$ & $\begin{array}{l}.5843 \\
.6070\end{array}$ \\
\hline $\begin{array}{l}\text { Cons. Women } \\
\text { Cons. Men }\end{array}$ & $\begin{array}{l}.34^{\mathrm{c}} \\
.49^{\mathrm{a}}\end{array}$ & $\begin{array}{l}.51 \\
.71^{\mathrm{a}}\end{array}$ & $\begin{array}{r}6.25^{*} \\
11.45^{*}\end{array}$ & $\begin{array}{l}.45^{\mathrm{c}} \\
.60^{\mathrm{a}, \mathrm{c}}\end{array}$ & $\begin{array}{l}.39^{\mathrm{c}} \\
.51^{\mathrm{a}}\end{array}$ & $\begin{array}{l}1.64 \\
3.97 *\end{array}$ \\
\hline All Cases & .40 & .58 & & .46 & .46 & \\
\hline
\end{tabular}

Note: Results for first two columns apply only for senators up for reelection. *Significant across

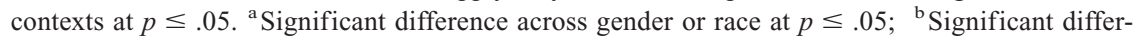
ences across gender within racial groups at $p \leq .05$; ${ }^{\mathrm{c}}$ Significant difference across race or ideology within gender group at $p \leq .05$. One-tailed test. 
the results in the first two columns of Table 2 apply only to senators facing reelection.

In general, I find strong environmental effects. When a female candidate was on the ballot, accuracy rates were, on average, 18 percentage points higher than in other states. Nonetheless, contrary to expectations, the effects of this variable are not necessarily greater for the issue publics examined in this article. For example, the effects of the female candidate variable are smaller for women generally, and for liberal women especially. Additionally, there are no differences between liberal and conservative men.

The last set of columns in Table 2 show results for living in a state represented by a Swing Democrat. These results provide additional qualified support for my hypothesis. Contrary to expectations, residing in one of these states makes no significant difference for most of the groups. Moreover, conservative men were slightly less attentive in these states. African Americans represent the one exception to this trend. Accuracy rates increase by $14 \%(p \leq .01)$ for blacks living in the mostly southern states represented by Swing Democrats. Moreover, only in these states do traditional racial differences in information levels reverse themselves ( $p \leq .11$ for a one-tailed test).

The bi-variate comparisons in Tables 1 and 2 yield only mixed support for the issue salience and context hypotheses. Still, it is possible that stronger results will emerge from a multi-variate framework. These results are reported in Table 3. The first pair of columns present the ordered logit regression coefficients and standard errors for analysis of the political knowledge scale. ${ }^{8}$ Analysis of the Gulf War vote is shown in the two middle columns and the Thomas vote is analyzed in the final two columns.

As proponents of the "generalist" argument would expect, levels of general political information were also highly associated with levels of specific political information. For example, the coefficient of 1.47 in the Thomas model indicates that the most highly informed male respondent (i.e., "1" on the political information scale) has a .78 probability of accurately identifying the vote of at least one of his senators. The probability is .45 for the least informed male respondent, all else equal. The effects were considerably weaker for women. The most politically informed woman has a .62 probability of identifying the vote of one of her senators while the probability is only .46 for the least informed.

The effects of the political environment variables are generally consistent with my expectations. ${ }^{9}$ For example, the coefficient of .65 on the female can-

\footnotetext{
${ }^{8}$ Ordered logistic regression is used because the dependent variables are categorical.

${ }^{9}$ One exception is the negative sign on the election variable in the Thomas model. This indicates that respondents were somewhat less informed about the vote of their senator if he or she was up for reelection in 1992 (see Alvarez and Gronke 1996, for similar results). The variable measuring the competitiveness of the election has the opposite sign, however, suggesting that the negative effects of elections apply primarily to senators facing weak challengers. Apparently, these senators have an incentive to obfuscate their position on controversial issues (Page 1978). Incumbents with strong challengers, however, cannot adopt this strategy as easily.
} 
TABLE 3

\section{Ordered Logit Regression Models Predicting Levels of Political Information, Knowledge of Senator's Vote on the Gulf War Use of Force Resolution, and the Confirmation of Clarence Thomas to the US Supreme Court}

\begin{tabular}{|c|c|c|c|c|c|c|}
\hline \multirow{2}{*}{$\begin{array}{l}\text { INDEPENDENT } \\
\text { VARIABLES }\end{array}$} & \multicolumn{2}{|c|}{$\begin{array}{l}\text { Political } \\
\text { Information }\end{array}$} & \multicolumn{2}{|c|}{ Gulf War } & \multicolumn{2}{|c|}{ Thomas } \\
\hline & Logit & Std. Error & Logit & Std. Error & Logit & Std. Error \\
\hline Political Information $(0-1)$ & \multicolumn{2}{|c|}{ - } & $1.34 * * *$ & $(.27)$ & $1.47 * * *$ & $(.27)$ \\
\hline Media Use $^{\mathrm{a}}(0-7)$ & $.05^{* *}$ & $(.02)$ & $.06 * * *$ & $(.02)$ & $.04 *$ & $(.02)$ \\
\hline Education (1-5) & $.26^{* * * *}$ & $(.03)$ & $.13 * * *$ & $(.03)$ & $.12 * * *$ & $(.03)$ \\
\hline Party Strength ${ }^{\mathrm{b}}(0-3)$ & .05 & $(.04)$ & $.15^{* * *}$ & $(.04)$ & $.10^{* *}$ & $(.04)$ \\
\hline Campaign Interest (1-3) & $.51 * * *$ & $(.07)$ & $.22 * * *$ & $(.07)$ & .10 & $(.07)$ \\
\hline Age (17-97) & $.01 * * *$ & $(.00)$ & $-.01 * * *$ & $(.00)$ & $-.01 * * *$ & $(.00)$ \\
\hline Years in State $(0-89)$ & $-.01 * *$ & $(.00)$ & $.01 * * *$ & $(.00)$ & $.01 * * *$ & $(.00)$ \\
\hline Abortion Attitudes (1-3) & $.20 *$ & $(.10)$ & .05 & $(.10)$ & .00 & $(.10)$ \\
\hline Thomas/War ${ }^{\mathrm{c}}(0-1)$ & $.77 * * *$ & $(.11)$ & $.61 * * *$ & $(.11)$ & $.93 * * *$ & $(.12)$ \\
\hline Ideology $(1-7)$ & -.00 & $(.05)$ & -.05 & $(.05)$ & $-.08 *$ & $(.05)$ \\
\hline Ideological Strength $^{\mathrm{b}}(0-3)$ & $.16^{* *}$ & $(.06)$ & -.01 & $(.06)$ & .05 & $(.06)$ \\
\hline Female $(0-1)$ & $-.90 * * *$ & $(.36)$ & $-1.07^{*}$ & $(.38)$ & $-1.04 * *$ & $(.38)$ \\
\hline Black $(0-1)$ & $-.73 * * *$ & $(.20)$ & -.31 & $(.20)$ & -.12 & $(.20)$ \\
\hline Swing Democrat $(0-1)$ & .07 & $(.12)$ & .17 & $(.12)$ & .07 & $(.12)$ \\
\hline Female Candidate $(0-1)$ & .04 & $(.12)$ & .01 & $(.13)$ & $.65^{* * *}$ & $(.12)$ \\
\hline Election in State $(0-1)$ & $-.29 *$ & $(.16)$ & -.04 & $(.16)$ & $-.50 * * *$ & $(.16)$ \\
\hline Competitive Election (0-4) & $.14 * *$ & $(.06)$ & -.02 & $(.06)$ & $.12 *$ & $(.05)$ \\
\hline \multicolumn{7}{|l|}{ Interaction variables } \\
\hline Black * Swing Democrat $(0-1)$ & -.18 & $(.32)$ & .36 & $(.31)$ & $.69 * *$ & $(.31)$ \\
\hline Female $*$ Ideology $(0-7)$ & .08 & $(.07)$ & .08 & $(.07)$ & $.15^{* *}$ & $(.07)$ \\
\hline Female * Ideo. Strength $(0-3)$ & -.04 & $(.08)$ & $.22 * *$ & $(.08)$ & $.14^{*}$ & $(.08)$ \\
\hline Female * Abortion Attitude $(0-3)$ & .11 & $(.13)$ & .16 & $(.13)$ & .16 & $(.13)$ \\
\hline Female $*$ Information $(0-1)$ & \multicolumn{2}{|c|}{ - } & $-.91 * *$ & $(.37)$ & $-.80 *$ & $(.37)$ \\
\hline Log likelihood & \multicolumn{2}{|c|}{-2792.50} & \multicolumn{2}{|c|}{-2319.79} & \multicolumn{2}{|c|}{-2401.81} \\
\hline Chi Square & \multicolumn{2}{|c|}{491.86} & \multicolumn{2}{|c|}{343.76} & \multicolumn{2}{|c|}{342.84} \\
\hline Number of Cases & \multicolumn{2}{|c|}{2354} & \multicolumn{2}{|c|}{2311} & \multicolumn{2}{|c|}{2354} \\
\hline
\end{tabular}

Note: ${ }^{*} p \leq .05 ; * * p \leq .01 ; * * * p \leq .001$ for One-tailed test, except constant. ${ }^{\text {a }}$ This variable is a combination of two questions measuring how many days in the past week that the respondent watched news programs on TV or read a daily newspaper. The variables were combined and divided by two. ${ }^{\mathrm{b}}$ These variables measure the strength of the respondent's partisan or ideological attachment. Higher values indicate a stronger attachment to either the Republican or Democratic party, or conservative or liberal ideology. ${ }^{c}$ Respondents who took no position on the Gulf War vote or the Thomas vote were coded as " 0 ," and respondents who either supported or opposed the action were coded as "1." In the Gulf War model, only the Gulf War attitude question was included whereas in the Thomas and Information models, only the Thomas attitude question was included. 
didate variable indicates that, all else equal, respondents in these states have a .69 probability of accurately identifying the vote of at least one of their senators. For respondents in other states the probability is only .54. The presence of female Senate candidates had no significant effect on levels of political information or attentiveness to the Gulf War vote. ${ }^{10}$

Table 3 also reveals evidence of selective attentiveness among conservative men but only mixed results for liberal women. For example, the ideology coefficient in the Thomas model is significant and negative, indicating that conservative men were more accurate than were liberal men. The ordered logit model predicts that a conservative man has a .71 probability of identifying how at least one of his senators voted on the Thomas nomination. The equivalent probability for a liberal man is only .59. In the other two models, differences between these groups were either insignificant or favor liberal men. The effects of ideology are different for women in the Thomas model, as shown by the positive interaction term. This indicates that liberal women have a .68 probability of identifying the vote of at least one senator, whereas for conservative women, the probability is only .58. Still, differences between liberal women and liberal men are not statistically significant. ${ }^{11}$

The multivariate analysis also reveals racial differences in information levels on the Thomas confirmation vote. Overall, the black-white knowledge gap, still evident for the political information and the Gulf War models, diminishes to almost zero on the Thomas vote. More importantly, however, residence in a state with a swing Democrat significantly increases accuracy rates for black respondents. The model predicts that the probability that an African American in these states will know the position of at least one of their senators is .69, versus a probability of .51 in all other states. For whites the probabilities are .55 and .54 , respectively.

\footnotetext{
${ }^{10}$ An alternative interpretation is that female candidates were more likely to run in states where citizens were already aware of and angry about their incumbent's vote. Although this seems to be a plausible hypothesis, the explanation fails both logically and empirically. Of the eight challengers included in this variable, only two-Yeakel (PA) and Mosley-Braun (IL) - seem to fit the description. The argument is more of a stretch for the remaining challengers. For example, Dianne Feinstein (CA) declared her intentions to run for the Senate before the Thomas controversy, and Charlene Haar (SD) challenged a Democratic opponent of Thomas. There was no expectation that the other incumbents would oppose Thomas and thus little grounds for anger. Still, if the alternative explanation is true, then the "female candidate" coefficient should decrease with the exclusion of Pennsylvania and Illinois. Also, attitudes toward Thomas should be more extreme in states with female candidates. Neither assumption is supported.

${ }^{11}$ When assessing the significance of an interaction, Jaccard, Turrisi, and Wan (1990) suggest examining how the slope on the interaction term varies as the values of the main effects change. In other words, they recommend that a coefficient and standard error be calculated for every possible value of the interaction. Using the formula they provide, I find that liberal women are more accurate than liberal men, but the difference is not significant.
} 


\section{Issue Salience, the Political Environment and the 1992 Senate Elections}

Table 3 showed that issue salience and factors in the political environment can work both separately and interactively to increase political information levels. It seems likely, however, that the context effects will be greater for senators whose term of office was up in 1992. Recall that six of the 13 swing Democrats were up for reelection, and this contributed to their anxiety over the Thomas vote. Similarly, the female candidate variable should also be most strongly associated with attentiveness to senators facing reelection. An ideal way to test this proposition is to compare the effects of the environmental variables on senators up for reelection to the effects for senators in those same states who were not on the ballot. In other words, respondents in states with female Senate candidates or with swing Democrats on the ballot should have been more informed of their incumbent's vote than they were about senators who were not up for reelection. Moreover, these environmental cues should have been especially pronounced for those respondents most engaged by the political campaign - the voters. For this reason, the analysis of information levels for senators facing reelection in 1992 only included respondents who voted in the Senate elections.

Table 4 presents the logistic regression coefficients for senators facing reelection in 1992 and for senators in those same states who were not on the ballot. As in Table 3, the models controlled for a variety of demographic and attitudinal factors. A number of important findings emerge from this table. First, I find that blacks in states with swing Democrats on the ballot were significantly more likely than their white counterparts to identify accurately their senator's vote on the Thomas nomination. This variable falls well short of statistical significance for senators in these same states who were not up for reelection. Secondly, the effects of female Senate candidates are significantly positive for senators facing reelection but indistinguishable from zero for senators not on the ballot. Finally, the abortion-by-gender interaction, that did not achieve significance in Table 3, is significant in Table 4, but only for senators facing reelection.

In order to appreciate the size of these effects, the coefficients were converted into predicted probabilities, as shown in Table 5. As expected, the effects of the contextual variables are much larger for senators facing reelection than for senators not facing reelection. For example, voters in states with female candidates were .29 points more likely to identify accurately the vote of the incumbent than were voters in states without female candidates. The effect of this variable for senators not up for reelection is almost zero. Similarly, black voters were approximately .29 points more likely than whites to identify the vote of swing Democrats. However, blacks are only .08 points more accurate than whites for the senators not up for reelection in these same states. 
TABLE 4

Logistic Regression Models Predicting Knowledge of Senator's Vote on the Confirmation of Clarence Thomas to the U.S. Supreme Court

\begin{tabular}{|c|c|c|c|c|}
\hline \multirow[b]{2}{*}{ INDEPENDENT VARIABLES } & \multicolumn{2}{|c|}{ Not Facing Reelection } & \multirow{2}{*}{$\frac{\text { Facing Reelection }}{\text { Logit }}$} & \multirow[b]{2}{*}{ Std. Error } \\
\hline & Logit & Std. Error & & \\
\hline Intercept & $-.99+$ & $(.71)$ & $-1.70 * *$ & $(.73)$ \\
\hline Political Information & $2.01 * * *$ & $(.54)$ & $2.16^{* * *}$ & $(.56)$ \\
\hline Media Use & -.01 & $(.04)$ & .01 & $(.04)$ \\
\hline Education & $.12 *$ & $(.06)$ & $.12 *$ & $(.06)$ \\
\hline Party Strength & .03 & $(.08)$ & $.13 *$ & $(.08)$ \\
\hline Campaign Interest & .02 & $(.13)$ & -.15 & $(.14)$ \\
\hline Age & -.00 & $(.00)$ & $-.01+$ & $(.01)$ \\
\hline Years in State & -.00 & $(.00)$ & $.01 *$ & $(.00)$ \\
\hline Abortion Attitudes & $-.33 *$ & $(.18)$ & .02 & $(.19)$ \\
\hline Supported or Opposed Thomas & $1.08 * * *$ & $(.23)$ & $.84 * * *$ & $(.23)$ \\
\hline Ideology & -.08 & $(.09)$ & $-.15 *$ & $(.09)$ \\
\hline Ideological Strength & -.04 & $(.12)$ & -.06 & $(.13)$ \\
\hline Female & $-1.53^{*}$ & $(.73)$ & $-1.63 * *$ & $(.75)$ \\
\hline Black & .05 & $(.33)$ & -.06 & $(.34)$ \\
\hline Swing Democrat & -.07 & $(.20)$ & -.14 & $(.21)$ \\
\hline Female Candidate & .10 & $(.16)$ & $1.18 * * *$ & $(.17)$ \\
\hline Competitive Election & .01 & $(.08)$ & $.19 * *$ & $(.08)$ \\
\hline \multicolumn{5}{|l|}{ Interaction variables } \\
\hline Black* Swing Democrat & .26 & $(.53)$ & $1.27 * *$ & $(.56)$ \\
\hline Female* Ideology & $.24 *$ & $(.12)$ & $.17+$ & $(.12)$ \\
\hline Female* Ideological Strength & .19 & $(.16)$ & .04 & $(.16)$ \\
\hline Female* Abortion Attitude & .25 & $(.24)$ & $.50^{*}$ & $(.25)$ \\
\hline Female* Information & $-1.23^{*}$ & $(.73)$ & $-1.33 *$ & $(.75)$ \\
\hline$\%$ Predicted Correctly & \multicolumn{2}{|c|}{60.74} & \multicolumn{2}{|l|}{65.24} \\
\hline Chi. Square & \multicolumn{2}{|c|}{95.59} & \multicolumn{2}{|l|}{149.37} \\
\hline-2 Log Likelihood & \multicolumn{2}{|c|}{1136.57} & \multicolumn{2}{|l|}{1082.60} \\
\hline $\mathrm{N}$ & \multicolumn{2}{|c|}{889} & \multicolumn{2}{|l|}{889} \\
\hline
\end{tabular}

Note: Table includes results for Senate election voters only. $+p \leq .10 ;{ }^{*} p \leq .05 ;{ }^{* *} p \leq .01$; ${ }^{* * *} p \leq .001$ for One-tailed test, except for constant.

\section{Selective Attentiveness and Political Support}

I showed in the previous section that issue salience, the appropriate political environment, and (in at least one case) their interaction can increase attentiveness to political issues. What we do not know is what role these variables played in the 1992 Senate elections. The answer to this question is important because it has implications for the ability of the voter to carry out his or her democratic obligations. In other words, if the political context and perceptions of issue importance can affect information levels, but not voting behavior, then the abil- 
TABLE 5

\section{Predicted Accuracy Rates for the Thomas Confirmation Vote Among Various Sub-groups in States with Reelection Campaigns (Voters Only)}

\begin{tabular}{lcc}
\hline & Not Facing Reelection & Facing Reelection \\
\hline Gender & & \\
$\quad$ Women & .49 & .37 \\
Men & .61 & .51 \\
Race & & \\
Blacks & .50 & .36 \\
Whites & .49 & .37 \\
Ideology and Gender & & \\
Pro-Choice, Liberal Women & .66 & .51 \\
Pro-Choice, Liberal Men & .45 & .38 \\
Pro-Life, Conservative Women & .46 & .24 \\
Pro-Life, Conservative Men & .72 & .59 \\
Political Environment & & .46 \\
Electoral Competition: High & .50 & .33 \\
Electoral Competition: Low & .49 & .66 \\
Female Candidate & .52 & .37 \\
No Female Candidate & .49 & .63 \\
Blacks in Swing States & .55 & .34 \\
Whites in Swing States & .47 & \\
\hline
\end{tabular}

ity of these variables to strengthen the influence of the voter is considerably limited.

Other researchers have examined the impact of the Thomas vote on the 1992 Senate elections (Wolpert and Gimpel 1997). Their results are remarkably weak. For example, Wolpert and Gimpel found almost no evidence that groups with particular interest in the Thomas vote (i.e., blacks, women, and ideologues) were more likely to vote for or against their senator on the basis of this roll call (1997). Accurate knowledge of the Thomas vote only aided the vote choice of respondents with opinions on the Thomas nomination and (in the case of Senate supporters of Thomas) pro-choice voters.

The conclusion that interest in the Thomas vote had no significant impact on the 1992 Senate elections might be premature. Congressional scholars have long noted that members of Congress are rarely concerned about the electoral consequences of any one vote (Fenno 1978; Kingdon 1973). When a vote does raise a problem, it is typically when legislators vote against the wishes of a significant number of their constituents (Miller and Stokes 1963). Thus, it is unlikely that many citizens would vote to reward the behavior of their senators on the Thomas vote. It is far more likely that they would seek to punish way- 
ward senators. Moreover, voters are also more likely to rely upon a single vote when they are on the losing side of an issue (Arnold 1990; Fenno 1996). In other words, citizens are more likely to use a single roll call as a basis for voting when they have incurred some political cost.

All of the above research suggests that the group most likely to have used the Thomas vote as a guide to their vote decision would be liberal women. The other two groups focused upon in this article, blacks and conservative men, were on the winning side of the Thomas vote and so presumably should not have relied heavily on this vote when casting their ballots. Moreover, in those states where blacks and conservative men were most concentrated (i.e., the south), senators of both parties largely supported the nomination. Only liberal women would potentially have the motivation and opportunity to punish their senators.

One way they could carry out this punishment is by voting against the supporters of Thomas. The problem with this expectation, however, is that most supporters of Thomas were Republicans. Liberal women could not plausibly punish these senators by withdrawing their support because they were not likely to support them in any case. The senators most likely to be damaged politically by the opposition of liberal women were the Democratic supporters of Thomas. Still, it is unlikely that liberal women would vote for the Republican challengers of these swing Democrats. A second and more desirable option available to liberal women who knew how these senators had voted, and disapproved of their decision, was to not vote at all. Just as perceived policy responsiveness may encourage participation among some citizens, the lack of responsiveness may also discourage participation (Bobo and Gilliam 1990). Fenno provides some support for this hypothesis. In his 1996 book, Senators on the Campaign Trail, he notes that Senator Fowler (D-GA), one of the swing Democrats up for reelection in 1992, encountered some trouble from this constituency because of this vote (Fenno 1996). ${ }^{12}$

One way to test this hypothesis is to examine turnout rates among liberal women especially in states represented by swing Democrats. Table 6 presents the results of a logistic regression analysis of voter turnout, controlling for all the traditional demographic and attitudinal variables. The data have been divided into states with senators opposing the Thomas nomination and states with senators who supported the nomination. The data are further divided among men and women with the expectation that only liberal women would make the strategic decision to avoid voting rather than to support pro-Thomas Democrats.

The relevant variable in each of the four models is the triple interaction capturing turnout rates for liberal respondents who knew how their Democratic senator voted on the Thomas nomination. If liberal women were interested in

\footnotetext{
12 “[Fowler's] single most harmful failure to keep in touch involved his inattentiveness to a core element of his 1986 coalition - the strongly supportive liberal, pro-choice women who had become disaffected in the wake of his vote in support of conservative, anti-abortion Clarence Thomas for the Supreme Court" (Fenno 1996, p. 194).
} 
TABLE 6

\section{Logistic Regression Models Predicting Voter Turnout by Gender and Senator's Support for Thomas Nomination}

\begin{tabular}{|c|c|c|c|c|}
\hline \multirow[b]{2}{*}{ INDEPENDENT VARIABLES } & \multicolumn{2}{|c|}{ Senator Opposed Thomas } & \multicolumn{2}{|c|}{ Senator Supported Thomas } \\
\hline & Men & Women & Men & Women \\
\hline Intercept & $\begin{array}{c}-4.19 \\
(3.20)\end{array}$ & $\begin{array}{c}-5.67 * * \\
(2.68)\end{array}$ & $\begin{array}{c}-9.62 * * * \\
(1.73)\end{array}$ & $\begin{array}{c}-4.24 * * * \\
(1.15)\end{array}$ \\
\hline Political Information & $\begin{array}{l}1.46^{* *} \\
(.88)\end{array}$ & $\begin{array}{c}.56 \\
(1.07)\end{array}$ & $\begin{array}{l}2.14^{* * * *} \\
(.81)\end{array}$ & $\begin{array}{l}1.79 * * * \\
(.70)\end{array}$ \\
\hline Media Use & $\begin{array}{l}.05 \\
(.10)\end{array}$ & $\begin{array}{l}.17^{* *} \\
(.09)\end{array}$ & $\begin{array}{l}.17^{* *} \\
(.09)\end{array}$ & $\begin{array}{l}.07 \\
(.08)\end{array}$ \\
\hline Education & $\begin{array}{l}.32 * * \\
(.05)\end{array}$ & $\begin{array}{l}.37^{* * *} \\
(.15)\end{array}$ & $\begin{array}{l}.09 \\
(.14)\end{array}$ & $\begin{array}{l}.11 \\
(.11)\end{array}$ \\
\hline Family Income & $\begin{array}{l}.08 \\
(.15)\end{array}$ & $\begin{array}{l}.31 * * \\
(.15)\end{array}$ & $\begin{array}{l}.54 * * * \\
(.14)\end{array}$ & $\begin{array}{l}.18^{* *} \\
(.11)\end{array}$ \\
\hline Strength of Partisanship & $\begin{array}{c}-.05 \\
(.17)\end{array}$ & $\begin{array}{l}.48^{* * *} \\
(.19)\end{array}$ & $\begin{array}{l}.38^{* *} \\
(.18)\end{array}$ & $\begin{array}{l}.34^{* * *} \\
(.14)\end{array}$ \\
\hline Interest in Campaigns & $\begin{array}{l}.86^{* * *} \\
(.25)\end{array}$ & $\begin{array}{l}1.28^{* * *} \\
(.30)\end{array}$ & $\begin{array}{l}1.14^{* * *} \\
(.29)\end{array}$ & $\begin{array}{l}.63^{* * *} \\
(.22)\end{array}$ \\
\hline Age & $\begin{array}{l}.03 * * * \\
(.01)\end{array}$ & $\begin{array}{l}.03 * * * \\
(.01)\end{array}$ & $\begin{array}{l}.03 * * * \\
(.01)\end{array}$ & $\begin{array}{l}.02 * * * \\
(.01)\end{array}$ \\
\hline Ideology & $\begin{array}{c}-.04 \\
(.80)\end{array}$ & $\begin{array}{c}-.40 \\
(.49)\end{array}$ & $\begin{array}{l}.57^{* *} \\
(.31)\end{array}$ & $\begin{array}{l}.00 \\
(.20)\end{array}$ \\
\hline Black & $\begin{array}{l}1.27 * * \\
(.62)\end{array}$ & $\begin{array}{c}-.45 \\
(.65)\end{array}$ & $\begin{array}{r}-.77 * \\
(.56)\end{array}$ & $\begin{array}{l}.38 \\
(.46)\end{array}$ \\
\hline Democratic Senator & $\begin{array}{l}-.46 \\
(3.18)\end{array}$ & $\begin{array}{c}-1.91 \\
(2.41)\end{array}$ & $\begin{array}{c}.85 \\
(1.61)\end{array}$ & $\begin{array}{l}-.24 \\
(1.24)\end{array}$ \\
\hline Competitive Election & $\begin{array}{c}.17 \\
(.24)\end{array}$ & $\begin{array}{c}-.12 \\
(.24)\end{array}$ & $\begin{array}{c}.03 \\
(.19)\end{array}$ & $\begin{array}{c}.03 \\
(.14)\end{array}$ \\
\hline Thomas Knowledge & $\begin{array}{r}.13 \\
(80.2)\end{array}$ & $\begin{array}{r}6.55 \\
(108.7)\end{array}$ & $\begin{array}{l}3.02 * * * \\
(1.37)\end{array}$ & $\begin{array}{l}-.86 \\
(1.09)\end{array}$ \\
\hline Dem. * Thomas Knowledge & $\begin{array}{c}.22 \\
(.53)\end{array}$ & $\begin{array}{r}-5.69 \\
(108.7)\end{array}$ & $\begin{array}{c}-2.51 \\
(2.66)\end{array}$ & $\begin{array}{c}2.62 * \\
(1.95)\end{array}$ \\
\hline Democrat * Ideology & $\begin{array}{c}-.09 \\
(.82)\end{array}$ & $\begin{array}{c}.42 \\
(.52)\end{array}$ & $\begin{array}{c}-.57^{*} \\
(.41)\end{array}$ & $\begin{array}{r}-.14 \\
(.33)\end{array}$ \\
\hline Ideo. * Thomas Knowledge & $\begin{array}{l}-2.86 \\
(31.5)\end{array}$ & $\begin{array}{r}.08 \\
(28.3)\end{array}$ & $\begin{array}{c}-.78 * * * \\
(.36)\end{array}$ & $\begin{array}{c}.28 \\
(.28)\end{array}$ \\
\hline Dem.* Thomas* Ideology & $\begin{array}{r}2.63 \\
(31.5)\end{array}$ & $\begin{array}{c}-.07 \\
(28.3)\end{array}$ & $\begin{array}{l}.80 \\
(.70)\end{array}$ & $\begin{array}{c}-.74 * \\
(.50)\end{array}$ \\
\hline-2 Log Likelihood & 208.726 & 206.347 & 223.487 & 342.042 \\
\hline Chi Square & $65.265 * * *$ & $103.678 * * *$ & $113.962 * * *$ & $79.041 * * *$ \\
\hline $\mathrm{N}$ & 209 & 262 & 264 & 341 \\
\hline
\end{tabular}

Note: ${ }^{*} p \leq .10 ; * *^{*} \leq .05 ; * * * p \leq .01$ for One-tailed test, except for the constant. 
TABLE 7

\section{Predicted Turnout Rates in Senate Election for Strong Liberal and Strong Conservative Women by Partisanship of Incumbent}

\begin{tabular}{lcccc}
\hline & $\begin{array}{c}\text { Rep. } \\
\text { Senator } \\
\text { Opposed }\end{array}$ & $\begin{array}{c}\text { Rep. } \\
\text { Senator } \\
\text { Supported }\end{array}$ & $\begin{array}{c}\text { Dem. } \\
\text { Senator } \\
\text { Opposed }\end{array}$ & $\begin{array}{c}\text { Dem. } \\
\text { Senator } \\
\text { Supported }\end{array}$ \\
\hline Did Not Know How Senator Voted & & & & \\
$\quad$ Strong Liberal Women & .44 & .76 & .68 & .49 \\
$\quad$ Strong Conservative Women & .89 & .76 & .66 & .68 \\
Did Know How Senator Voted & & & & \\
$\quad$ Strong Liberal Women & .99 & .91 & .85 & .19 \\
Strong Conservative Women & .99 & .64 & .82 & .89 \\
\hline
\end{tabular}

Note: "Opposed" refers to senators voting against the Thomas nomination and "Supported" refers to Senators supporting the nomination. Predicted values based on strong liberals (i.e., ideology equals "7") and strong conservatives (i.e., ideology equals "1"), with all other variables held to their mean or median.

punishing Democratic supporters of Thomas by not voting then the triple interaction should be negative and statistically significant in the final column of Table 6. This expectation is confirmed $(p \leq .07)$. Interestingly, these women were also less likely to vote in the presidential election (results not shown). This suggests that political disaffection among this group did not derive entirely from the Thomas vote. Perhaps candidate Clinton's decision to run as a "new Democrat" also undermined liberal women's political enthusiasm. Still, whatever range of factors may have contributed to their decision, it is clear that the Thomas vote had a significant influence.

In order to get a sense of the magnitude of this effect the coefficients are converted into predicted probabilities, as reported in Table 7. Only results for strong conservative and strong liberal women (i.e., " 1 " and " 7 " on the ideological scale) are reported. ${ }^{13}$ We see in the final column of Table 7 that liberal women with accurate knowledge of the Thomas vote had an especially low probability of voting in states represented by Democratic supporters of the nomination. This represents a marked contrast to the participation rates of informed

\footnotetext{
${ }^{13}$ These probabilities should be interpreted with some caution. As one might expect, given the relatively small state samples in the SES, the predicted probabilities are based on very few cases. For example, there were only 12 self-described liberal women in states represented by Democratic supporters of Thomas, and only two were strong liberals. Still, the raw percentages tell a similar story. The percentage of liberal women (weak and strong) in these states who actually reported voting is $50 \%$ compared to $88 \%$ of liberal women in other states and $86 \%$ of conservative women in states represented by swing Democrats. Both sets of comparisons are statistically significant at the .05 level.
} 
conservative women, within these same states. ${ }^{14}$ At a minimum, these results suggest that these liberal women remembered their senator's vote on the controversial nomination and decided to send a message by staying home.

\section{Conclusion}

The principal question this study sought to answer was whether perceptions of issue salience and external political factors increase levels of political information. The results indicate that these factors are important both separately and interactively. For example conservative men, and to a lesser extent liberal women, were significantly more knowledgeable of their senator's vote on the Thomas nomination than were relevant comparison groups. I also showed that these respondents were generally not more knowledgeable about politics when their group interests were not primed. Moreover, factors in the political environment, such as the presence of female Senate candidates, also increased accuracy rates. On matters where the gender of the candidates was less important (i.e., the Gulf War vote and the political information scale), this variable had no effect.

The interaction of salience and political context also affected accuracy rates, although not always in the manner hypothesized. I expected that group members with special interests in the Thomas vote would be even more accurate in states represented by swing Democrats. This turned out to be true, however, only for African Americans. Still, these effects were considerable, especially for senators facing reelection. For these senators, blacks not only closed the traditional racial gap in political information, but they also surpassed comparable whites.

Finally, the interaction of salience and political context also influenced participation rates. Although the evidence among liberal women for heightened attentiveness to the Thomas vote was mixed, those who did know how their senator voted responded differently than comparable groups. Liberal women with accurate knowledge of the Thomas vote were significantly less likely to participate in their local Senate elections in states where the incumbent Democrat supported Thomas. Participation rates among others were unaffected by knowledge of this vote.

Why has other research in this area uncovered less powerful and consistent evidence of selective attentiveness? Undoubtedly, part of the answer is that researchers have not always looked in the right places. While using group membership as a proxy for issue salience is appropriate, researchers need to recognize

\footnotetext{
${ }^{14}$ Using the formula referred to in note 11 confirms that turnout was significantly different between informed liberals and informed conservatives $(\mathrm{t}-\mathrm{ratio}=-1.82)$. This same formula also shows that informed liberal women represented by Democratic senators were significantly more likely to vote if their senator opposed Thomas $(t-r a t i o=2.22)$. However, informed liberals did not have significantly different turnout rates relative to uninformed liberals in states represented by Democratic supporters of Thomas (t-ratio $=-1.02)$.
} 
the importance of overlapping group memberships. Sometimes, these different memberships can cancel out any anticipated effects. Failure to take this complication into account can lead to an underestimation of salience effects. For example, researchers operating under the assumption that most conservatives were concerned about the outcome of the Thomas vote would have found little evidence of selective attentiveness.

Another reason why some previous work has found limited support for the issue salience hypothesis is that insufficient attention has been paid to the political context. As the results of this study demonstrate, salience effects can at times be enhanced by factors in the local political environment. Bobo and Gilliam (1990) have already shown that this can occur with changes in control of the mayor's office. This study shows that more subtle differences in the political environment can also increase information levels.

With regard to the debate between the generalist and the specialist models of political information processing, this article provides only a limited resolution. Both models account for some of the variation in respondents' knowledge of their senators' vote on the Thomas nomination. The generalist model, however, works much better for men than for women. Among men, the effects of the general measure of political knowledge are usually about twice the size of the salience measures. Among women, the effects are more comparable.

Overall, the democratic implications of these findings are somewhat reassuring. This is because they suggest that, although the electorate may be generally uninformed on political matters, citizens concerned with particular issues are unusually attentive to their representative's position on those issues. Still, this interpretation should not be carried too far. The results of this study only apply to one highly publicized roll call. Whether or not similar results would emerge for less prominent votes awaits future research.

Finally, identifying how much various groups knew about the position of their senators on the Thomas nomination helps to explain why Thomas succeeded in spite of the controversy sparked by his hearings. This study confirms that senators were right to be concerned with how their constituents might react. The constituents whom senators feared would be especially attentive were indeed more informed than others. In the end, Thomas was successful because the issue publics most concerned with the vote were also not randomly distributed across the nation. The two groups most predisposed to support Thomasblacks and conservative men - represented a potent, although unusual coalition. They were also disproportionately concentrated in the states represented by swing Democrats.

The successful confirmation vote of Clarence Thomas to the U.S. Supreme Court was broadly responsive in the sense that most voters favored the nomination. The Senate vote was more narrowly responsive as well, however, because many senators paid special attention to the concerns of voters with the most intense opinions on this issue. In spite of the consistent finding that information levels are typically low, legislators likely feared that if they voted "in- 
correctly" interested voters would learn of this and exact retribution at the ballot box. At a minimum, the results in this article suggest that this concern was a reasonable one.

Manuscript submitted 20 June 2000

Final manuscript received 21 November 2000

\section{References}

Alvarez, R. Michael, and Paul Gronke. 1996. "Constituents and Knowledge of Senate Roll Call Votes." Presented at the annual meeting of the American Political Science Association, San Francisco.

Arnold, R. Douglas. 1990. The Logic of Congressional Action. New Haven: Yale University Press.

Bennett, Stephen Earl. 1995. "Comparing Americans' Political Information in 1988 and 1992." The Journal of Politics 57(2): 521-32.

Berelson, Bernard, Paul Lazarsfeld, and William McPhee. 1954. Voting. Chicago: University of Chicago Press.

Bobo, Lawrence, and Franklin D. Gilliam, Jr. 1990. "Race, Sociopolitical Participation, and Black Empowerment." American Political Science Review 84(2): 377-93.

Burnham, Margaret A. 1992. "The Supreme Court Appointment Process and the Politics of Race and Sex." In Race-ing Justice, En-Gendering Power, ed. Toni Morrison. New York: Pantheon Books.

Campbell, Angus, Phillip E. Converse, Warren E. Miller, and Donald E. Stokes. 1960. The American Voter. New York: Wiley.

Caldeira, Gregory A., and Charles E. Smith, Jr. 1996. "Campaigning for the Supreme Court: The Dynamics of Public Opinion on the Thomas Nomination.” Journal of Politics 58(3): 655-81.

Chaffee, Steven H., and Donna G. Wilson. 1977. "Media Rich, Media Poor: Two Studies of Diversity in Agenda Holding." Journalism Quarterly 54(3): 466-76.

Conover, Pamela Johnston. 1984. "The Influence of Group Identifications on Political Perception and Evaluation." Journal of Politics 46(3): 760-84.

Converse, Philip E. 1964. "The Nature of Belief Systems in Mass Publics." In Ideology and Discontent, ed. David Apter. New York: Free Press.

Cook, Elizabeth Adell, Sue Thomas, and Clyde Wilcox. 1994. The Year of the Woman. Boulder, CO: Westview Press.

Delli Carpini, Michael X., and Scott Keeter. 1996. What Americans Know about Politics and Why it Matters. New Haven: Yale University Press.

Fenno, Richard. 1978. Home Style: House Members in Their Districts. New York: HarperCollins.

Fenno, Richard. 1996. Senators on the Campaign Trail: The Politics of Representation. Norman: University of Oklahoma Press.

Iyengar, Shanto. 1990. "Shortcuts to Political Knowledge: The Role of Selective Attention and Accessibility." In Information and Democratic Processes, eds. John H. Ferejohn and James H. Kuklinski. Urbana and Chicago: University of Illinois Press.

Iyengar, Shanto and Donald R. Kinder. 1987. News That Matters: Television and American Opinion. Chicago: University of Chicago Press.

Jaccard, James, Robert Turrisi, and Choi K. Wan. 1990. Interaction Effects in Multiple Regression. Newbury Park: Sage.

Kingdon, John W. 1973. Congressmen's Voting Decisions. New York: Harper and Row.

Krosnick, Jon A. 1990. "Expertise and Political Psychology.” Social Cognition 8(1): 1-8.

Mansbridge, Jane, and Katherine Tate. 1992. "Race Trumps Gender: The Thomas Nomination in the Black Community." PS: Political Science and Politics 25(3): 488-92. 
Marable, Manning. 1992. "The Supreme Court Appointment Process and the Politics of Race and Sex." In Race-ing Justice, En-Gendering Power, ed. Toni Morrison. New York: Pantheon Books.

Marcus, George E., and Michael B. Mackuen. 1993. "Anxiety, Enthusiasm, and the Vote: The Emotional Underpinnings of Learning and Involvement during Presidential Campaigns." American Political Science Review 87(3): 672-85.

McGraw, Kathleen M., and Neil Pinney. 1990. "The Effects of General and Domain-Specific Expertise on Political Memory and Judgment." Social Cognition 8(1): 9-30.

Miller, Warren E., and Donald E. Stokes. 1963. "Constituency Influence in Congress." American Political Science Review 57(1): 45-57.

Nueman, W. Russell. 1986. The Paradox of Mass Politics: Knowledge and Opinion in the American Electorate. Cambridge: Harvard University Press.

Overby, Marvin L., Beth M. Henschen, Michael H. Walsh, and Julie Strauss. 1992. "Courting Constituents? An Analysis of the Senate Confirmation Vote on Justice Clarence Thomas." American Political Science Review 86(4): 997-1003.

Paolino, Phillip. 1995. "Group Salient Issues and Group Representation: Support for Women Candidates in the 1992 Senate Elections." American Journal of Political Science 39(2): 294-313.

Page, Benjamin I. 1978. Choices and Echoes in Presidential Elections: Rational Man and Electoral Democracy. Chicago and London: University of Chicago Press.

Patterson, Thomas E. 1994. Out of Order. New York: Vintage Books.

Pinderhughes, Dianne M. 1992. "Divisions in the Civil Rights Community." PS: Political Science and Politics 25(3): 485-87.

Price, Vincent, and John Zaller. 1993. "Who Gets the News?" Public Opinion Quarterly 57(2): 133-64.

Sapiro, Virginia, and Pamela Johnston Conover. 1997. "The Variable Gender Basis of Electoral Politics: Gender and Context in the 1992 US Election." British Journal of Political Science 27(4): 497-523.

Smith, Eric R.A.N. 1989. The Unchanging American Voter. Berkeley: University of California Press.

Turner, John C., with Michael A. Hogg, Penelope J. Oakes, Stephen D. Reicher, and Margaret S. Wetherell. 1987. Rediscovering the Social Group: A Self-Categorization Theory. New York: Basil Blackwell.

Verba, Sidney, Nancy Burns, and Kay Lehman Scholzman. 1997. "Knowing and Caring about Politics: Gender and Political Engagement.” Journal of Politics 59(4): 1051-72.

Wolpert, Robin M., and James G. Gimpel. 1997. "Information, Recall, and Accountability: The Electorate's Response to the Clarence Thomas Nomination.” Legislative Studies Quarterly 22(4): 535-50.

Vincent L. Hutchings is assistant professor of political science, University of Michigan, Ann Arbor, MI 48104-3028. 